\title{
Eksplorasi Desain Motif Baru Batik Majapahit dengan Metode Desain Partisipatif
}

\author{
Ratna Sari Fajarwati dan Senja Aprela Agustin \\ Departemen Desain Komunikasi Visual, Fakultas Arsitektur Desain dan Perencanaan, \\ Institiut Teknologi Sepuluh Nopember (ITS) \\ e-mail:senja@kotasis.com
}

\begin{abstract}
Abstrak-Batik Majapahit konon telah ada sejak zaman Kerajaan Majapahit. Pengrajin batik Majapahit dalam skala industri kecil maupun menengah saat ini melakukan pengembangan motif sebagai upaya keikutsertaan mereka dalam menambah keragaman motif. Perlu adanya suatu upaya untuk terus mengembangkan jenis-jenis motif batik yang baru. Penelitian ini mengeksplorasi desain motif baru batik yang diadaptasi dari potensi daerah Mojokerto dan elemen-elemen yang ada dalam Kerajaan Majapahit. Menggunakan metode penelitian desain partisipatif, observasi, dan depth interview untuk mendapatkan data primer serta studi literatur dan studi eksisting untuk mendapatkan data sekunder. Metode yang diterapkan dalam kegiatan ini melalui pendekatan partisipatif kepada para calon pengguna. Tujuan dari metode desain partisipatif sendiri adalah peningkatan keragaman desain motif batik Majapahit yang mudah dan akan dikembangkan oleh pengrajin. Target audiens dari penelitian ini diutamakan untuk kalangan dewasa muda. Proses desain ini akan menghasilkan eksplorasi motif baru dalam bentuk buku tentang eksplorasi desain motif baru batik Majapahit serta media pendukung penelitian.
\end{abstract}

Kata Kunci-Batik Majapahit, Desain Partisipatif, Pengembangan Motif.

\section{PENDAHULUAN}

B ERMACAM eksplorasi batik telah dilakukan desainer mode, mulai dari eksplorasi secara tradisional maupun digital. Seperti daerah yang masih dalam tahap menggali potensi batik, kini berusaha mengembangkan batik yang berciri khas daerah mereka dan berusaha memunculkan kreasi baru dalam produk batik. Salah satu batik yang berusaha dikembangkan dan digali kekayaannya adalah batik Majapahit di daerah Mojokerto, Jawa Timur. Batik Majapahit mempunyai akar sejarah yang panjang yang terkait erat dengan sejarah peradaban Majapahit.

Tantangan bagi pengrajin saat ini yaitu bagaimana pengrajin dapat memasarkan batik untuk kalangan muda, karena karena saat ini batik Majapahit hanya digunakan sebagai seragam identitas pemerintahan dan pegawai negeri di Kota maupun Kabupaten Mojokerto. Pengembangan motif juga bertujuan untuk mengingatkan bahwa Mojokerto mempunyai berbagai macam potensi dan sejarah yang masih ada dan tetap harus dilestarikan. Salah satu upaya yang dapat dilakukan adalah dengan mengeksplorasi motif secara berkala agar motif khas Majapahit yang ditampilkan kian beragam dan dapat meningkatkan minat konsumen terhadap motif batik Majapahitan. Pengembangan motif batik Majapahit nantinya akan dirancang oleh penulis melalui pendekatan desain partisipatif.
Metode yang diterapkan dalam kegiatan ini meliputi pendekatan partisipatif kepada para calon pengguna yang meliputi pemilik usaha, pendesain motif, pembatik, tukang warna, dan karyawan dilibatkan ikut berpartisipasi secara aktif terhadap semua kegiatan riset sesuai dengan bidangnya masing-masing. Dengan demikian, mereka akan mampu memahami kebutuhan yang terkait dengan pekerjaan dan mampu memecahkan masalahnya. Tujuan dari metode desain partisipatif sendiri adalah peningkatan keragaman desain motif batik Majapahit yang mudah dan akan dikembangkan oleh pengrajin kedepannya.

Tahapan pengembangan desain motif batik ini pertama melakukan analisis terhadap motif batik Majapahit yang potensial berdasarkan produk yang telah dibuat. Kedua penyusunan konsep desain produk batik, misalnya untuk target dewasa muda dengan pemilihan warna tertentu, dan juga memproduksi batik disesuaikan dengan fungsinya, seperti sebagai jarit, baju, dan sebagainya. Konsep atau tujuan penerapan motif pada kain sesuai dengan perkembangan fashion zaman sekarang Pada umumnya kegunaan kain batik Majapahit sebagian besar dipakai untuk pakaian wanita dan pakaian pria.

A. Identifikasi Masalah

1. Batik Majapahit ini masih dalam proses membentuk identitas diri.

2. Belum adanya penelitian dan pengembangan yang memadai tentang eksplorasi motif batik Majapahit.

3. Pengembangan batik Majapahit ini belum melibatkan desainer dalam pembuatan motif.

4. Perlu adanya suatu inovasi dengan pendekatan partisipatif agar para pengrajin menghasilkan kerajinan batik tulis yang beragam.

\section{B. Rumusan Masalah}

Berdasarkan identifikasi masalah tersebut maka rumusan masalah yang diangkat dalam perancangan ini adalah "Bagaimana mengeksplorasi desain motif baru batik Majapahit dengan metode desain partisipatif?"

\section{C.Batasan Masalah}

1. Pada perancangan ini penulis hanya akan menyelesaikan masalah yang berhubungan dengan bidang desain yaitu dalam bidang eksplorasi dan menciptakan motif batik Majapahit.

2. Konten yang dibahas dalam perancangan ini berkaitan dengan hasil eksplorasi motif batik Majapahit yang baru dengan metode desain partisipatif.

3. Studi penelitian perancangan ini dibataskan pada lingkup Mojokerto. 
4. Media akhir yang akan digunakan pada perancangan ini adalah aplikasi eksplorasi motif batik dalam bentuk buku visual.

\section{D.Maksud dan Tujuan}

\section{Manfaat Akademik}

Ilmu desain komunikasi visual adalah ilmu yang mampu membantu memecahkan suatu masalah melalui sebuah media untuk mengenalkan, menyebarluaskan, mengedukasi, dan mendokumentasi eksplorasi desain motif baru batik Majapahit.

\section{Manfaat Praktisi}

Eksplorasi desain motif baru batik Majapahit ini dapat menjadi referensi bagi pengrajin batik, mahasiswa desain, fashion designer, kolektor batik dan masyarakat luas yang ingin mencari inspirasi dalam mengeksplorasi motif batik. Serta pada perancangan ini dapat membantu pemerintah dalam memperkenalkan potensi daerah terkait tentang desain motif baru batik Majapahit sebagai bahan penelitian.

\section{Manfaat Umum}

Eksplorasi desain motif baru batik Majapahit ini sebagai media referensi dan dokumentasi dalam menggali motif untuk para pengrajin dan pengusaha batik di Mojokerto. Dengan adanya perancangan ini juga dapat memperkaya keilmuan Desain Komunikasi Visual dalam merancang desain motif batik Majapahit yang baru.

\section{STUDI PUSTAKA}

\section{A. Landasan Teori}

1. Batik Majapahit

Teori ini mencakup tentang sejarah batik Majapahit, proses pembuatan hingga alat pendukung dalam proses pembuatan tenun ikat. Seluruh informasi ini didapat dari berbagai sumber literatur baik cetak maupun digital tentang batik di Indonesia khususnya Kabupaten Mojokerto.

2. Desain Partisipatif

Teori desain partisipatif menurut Bella Martin adalah tentang pendekatan yang melibatkan para pengguna dan pemangku kepentingan yang aktif di seluruh tahap penelitian dan proses desain, termasuk kegiatan desain komunikatif.

\section{Struktur Buku}

Buku secara umum tersusun atas bagian-bagian yang membangun buku menjadi sebuah struktur bahan cetakan yang layak untuk dibaca dan dikonsumsi oleh khalayak umum. Buku terdiri dari Preliminaries (pendahulu), prakata, daftar isi, bagian isi, dan postliminaries (penyudah).

\section{Layout Buku}

Teori layout menurut Surianto Rustan terdapat beberapa elemen dasar yang terkandung dalam layout yang diantaranya adalah elemen visual dan elemen teks.

\section{B. Studi Eksisting}

\section{Tinjauan Komparator}

Tinjauan komparator pada perancangan ini, mengkaji tentang eksplorasi motif pada fashion dengan produk yang bernama Sejauh Mata Memandang. Batik Sejauh Mata Memandang adalah salah satu produk fashion lifestyle yang didirikan oleh Chitra Subiyakto. Motif batik Sejauh Mata Memandang terinspirasi dari dalam kehidupan yang ada di Indonesia mulai dari kuliner, arsitektur, hingga perairan Indonesia.

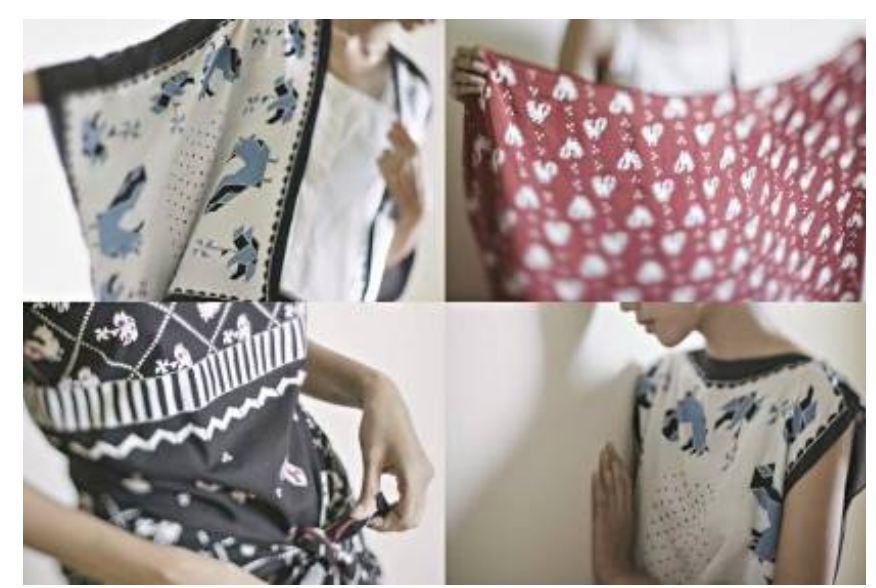

Gambar 1. Batik sejauh mata memandang.

Sumber: www.sejauh.com

Tinjauan komparator kedua pada perancangan ini, mengkaji tentang buku yang berjudul "Patterns : Inside The Design Library, The New Amazing Book By Phaidon". Buku ini adalah buku panduan terhadap arsip pola dan tekstil terbesar di dunia, sumber inspirasi bagi perancang busana kelas atas. Setiap musim, fashion designer, tekstil, seni grafis, dan industri produk kertas mencari inspirasi dari pola ini untuk membawa koleksi mereka ke kehidupan. Banyak perancang seperti Beacon Hill, Boden, Calvin Klein, Clinique, Colefax \& Fowler, Lululemon, Nike, Oscar de la Renta, Pottery Barn, dan mencari buku ini.

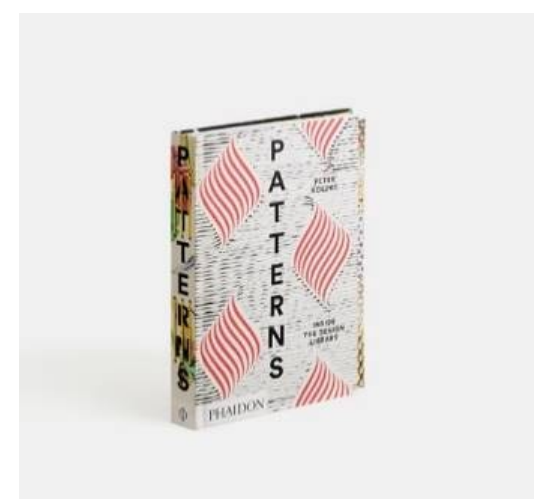

Gambar 2. "Patterns : Inside The Design Library, The New Amazing Book By Phaidon".

Sumber: www.phaidon.com

\section{Tinjauan Kompetitor}

Tinjauan kompetitor pada perancangan ini, mengkaji tentang eksplorasi motif pada batik dengan produk yang bernama Batik Komar adalah batik Komar merupakan salah satu produk unggulan batik dari daerah Bandung, Jawa Barat. Batik Komar berangkat dari ragam hias batik Cirebonan yang kemudian berkembang ke arah pembuatan desain motif yang lebih modern dengan kreasi yang unik, 


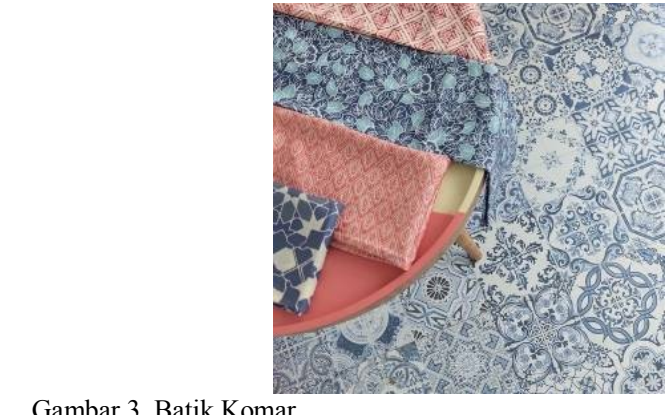

Gambar 3. Batik Komar.

Sumber: www.batikkomar.com

Tinjauan kompetitor kedua pada perancangan ini, mengkaji tentang buku yang berjudul "Keeksotisan Batik Jawa Timur". Dalam buku ini penulis dengan mengungkapkan motif tradisionalnya. Tak hanya itu, penulis juga menyisipkan banyak gambar agar pembaca mendapat gambaran yang jelas dan tidak ambigu mengenai masingmasing motif. Uniknya, penulis juga menambahkan sejarah singkat batik di masing-masing daerah.

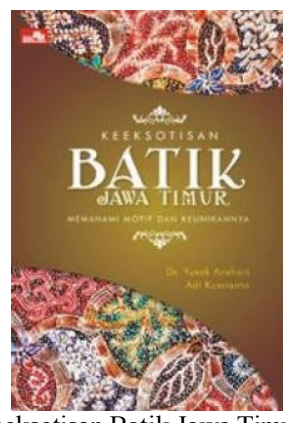

Gambar 4. Cover Buku Keeksotisan Batik Jawa Timur.

Sumber: https://bibliodit.wordpress.com/2016/12/08/keeksotisan-batik-jawatimur-dr-yusak-anshori-adi-kusrianto

\section{METODOLOGI PERANCANGAN}

\section{A. Segmentasi Pemasaran}

\section{Demografis}

Jenis kelamin : Laki-laki dan perempuan

Target audiens perancangan ini tidak dibatasi oleh jenis kelamin, karena yang berminat dengan batik tidak dibatasi oleh gender.

Usia : 20-35 tahun

Penulis memilih rentang usia 20-35 tahun karena, pada umur 20 tahun adalah umur yang produktif untuk memahami dan menilai kebudayaan terutama tentang batik. Penghasilan : > Rp 2.500.000

\section{Geografis}

Target audiens dari perancangan ini yaitu berdomisili di Indonesia khususnya di daerah kota besar seperti Jakarta, Surabaya, Mojokerto dan tiap ibu kota provinsi di Indonesia.

\section{Psikografis}

a. Memiliki minat dan ketertarikan terhadap budaya batik Majapahit.

b. Memiliki minat dan ketertarikan terhadap batik dalam fashion

c. Memiliki motivasi untuk melestarikan potensi daerah Mojokerto melalui motif batik.

d. Peduli dengan isu lingkungan

e. Memiliki rasa keingintahuan yang tinggi f. Kreatif dan berjiwa seni tinggi.

\section{B. Metode Kualitatif}

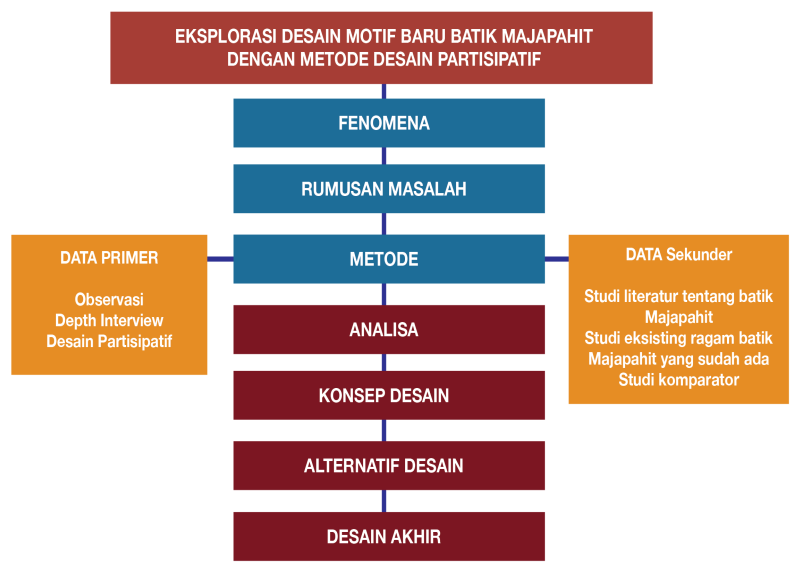

Gambar 5. Alur perancangan

Sumber: Fajarwati, 2019

\section{Observasi}

Observasi pada tanggal 10 April 2018 di tempat workshop pembuatan batik di daerah Kota dan Kabupaten Mojokerto, kemudian yang kedua terhadap potensi daerah Mojokerto.

2. Depth Interview

Depth interview dengan Disperindag Kabupaten Mojokerto. Wawancara dilakukan pada tanggal 10 April 2018 dilakukan untuk menggali informasi tentang sejarah munculnya batik di Mojokerto secara mendalam saat ini, yang mencakup tentang motif khas batik Mojokerto, proses produksi, dan permasalahan yang dihadapi sehingga dapat digunakan sebagai acaun penulis dalam proses pengambilan keputusan hasil akhir penelitian.

Depth interview dengan pengrajin batik di Mojokerto, wawancara dilakukan untuk mengetahui proses pembuatan batik Majapahit, ragam motif batik Majapahit yang telah dibuat, kriteria desain motif batik Majapahit, hambatan yang dihadapi pengerajin atau desainer batik Majapahit. Wawancara dilakukan pada berbagai tempat pengrajin yaitu antara lain batik NEGI, batik Ernawati, batik Putri Gunung, batik Cempaka.

Depth interview dengan budayawan batik di Mojokerto, wawancara ini bertujuan untuk Mendapatkan informasi mengenai acuan dan cara mendesain motif batik yang benar beserta langkahnya. Mempelajari batik Majapahit lebih dalam dan detail. Dan menganalisis studi eksisting ragam batik Majapahit.

3. Desain Partisipatif

Desain partisipatif dilakukan dengan beberapa tahapan yaitu:

a. FGD penyusunan desain awal

Mengidentifikasi individu atau kelompok utama untuk dilibatkan dalam penyusunan desain. Mendapatkan partisipasi awal calon peserta dalam mendesain motif batik Mendapatkan tanggapan dan masukan dari peserta FGD untuk penyempurnaan desain awal

b. Diskusi dan konsultasi desain

Mendapatkan keterlibatan calon pengguna dalam pemberian ide desain motif batik. Mendapatkan beberapa alternatif desain yang akan diimplementasikan. Mendapatkan 
kesepakatan bersama tentang desain yang akan diimplementasikan

\section{c. Prototyping}

Membuat prototype desain yang dibuat dan menganalisis warna alternatif yang dipakai.

d. Desain Akhir

Mengimplementasikan desain yang sudah disepakati kedalam bentuk digital dan kain.

\section{KONSEP DESAIN}

\section{A. Konsep Desain}

Konsep perancangan buku visual ini ditentukan berdasarkan hasil dari desain partisipatif, depth interview dan observasi yang telah dilakukan. Big idea dari perancangan ini adalah "Playful Exploring Batik Majapahit Motives". Konsep "Playful Exploring" sendiri memiliki arti eksplorasi yang menyenangkan, merupakan representasi dari konsep buku ini yang mengajak pembaca untuk ikut serta merasakan membuat motif batik sendiri. Sehingga maksud dari keyword ini adalah memacu pembaca untuk ikut serta membuat eksplorasi motif batik dari stilasi berbagai potensi Mojokerto serta elemen kebudayaan Kerajaan Majapahit kedalam sebuah motif.

\section{B. Struktur Buku}

Struktur konten buku ditentukan berdasarkan hasil analisis desain partisipatif dan depth interview. Buku visual batik Majapahit ini terdiri dari 5 bab. Berikut struktur konten yang digunakan dalam buku ini :

a. Bab 1 - Pendahuluan

b. Bab 2 - Sejarah awal batik Majapahit, desain partisipatif

c. Bab 3 - Kreasi padu padan motif batik, kreasi padu padan warna motif batik

d. Bab 4 - Pengaplikasian motif pada fashion

e. Bab 5 - Penutup

\section{Spesifikasi Buku}

a. Ukuran buku : $21 \mathrm{~cm} \times 26 \mathrm{~cm}$

b. Jumlah halaman : 108 halaman

c. Penggunaan warna full color

d. Isi buku menggunakan kertas hvs $100 \mathrm{~g}$

e. Di jilid hardcover dengan finishing laminasi doff

f. Binding benang

\section{Gaya Gambar}

Gaya gambar eksplorasi motif batik ini seperti ragam motif batik Majapahit sebelumnya, gaya gambar yang digunakan pada perancangan ini adalah menggunakan teknik stilasi yaitu menyederhanakan suatu bentuk tanpa merubah bentuk aslinya.

\section{E. Warna}

Penentuan palet warna pada perancangan batik mengggunakan palet warna yang diadaptasi dari warnawarna yang ada pada batik Majapahit yang sudah ada. Penggunaan warna pada 1 lembar kain sebanyak 2-5 warna untuk menyesuaikan dengan selera target dan keterbatasan kemampuan pengerajin. Kemudian warna disesuaikan dengan warna yang dimiliki pengerajin.
Kriteria yang digunakan pada motif utama adalah mencakup ornamen yang bersifat dominan, berukuran lebih besar dari isen-isen dan bersifat bebas.

\section{G.Isen-isen}

Kriteria isen-isen pada ragam motif batik Majapahit ini memiliki kriteria dengan tidak banyak ruang kosong, isen rapat tidak terlalu renggang, dan isen menyesuaikan motif utama.

\section{H.Cara Penggunaan Buku}

Buku ini menampilkan simulasi pembuatan motif batik Majapahit menggunakan material gambar, yang dapat di padu padankan sesuai keinginan pembaca.

\section{IMPLEMENTASI DESAIN}

\section{A. Stilasi}

Stilasi adalah tahapan penyeleksian kelompok gambar yang sesuai dengan kriteria gambar, tahap ini digunakan untuk menyusun dan mempersatukan gambar stilasi kedalam satu lembar kerja desain motif dengan metode morphological matrix. Kumpulan stilasi dimasukkan kedalam morphological matrix yang berguna untuk mempermudah dalam eksplorasi motif utama. Berikut tampilan salah satu morphological matrix:
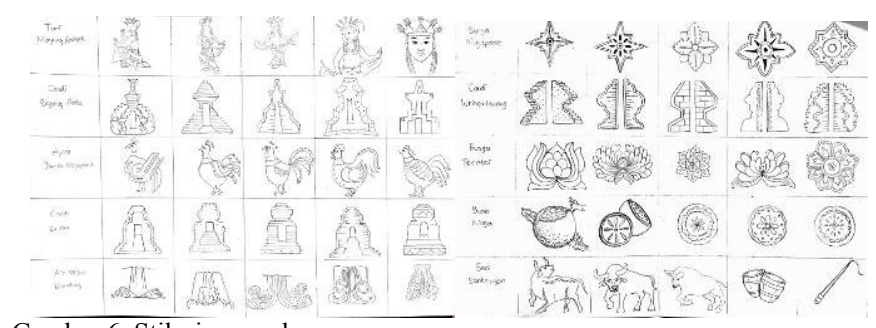

Gambar 6. Stilasi manual

Sumber: Fajarwati, 2018

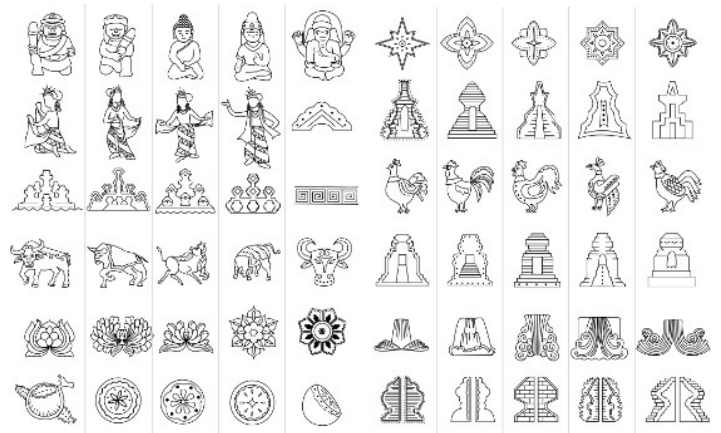

Gambar 7. Stilasi digital.

Sumber: Fajarwati, 2018

\section{B. Desain Partisipatif}

Setelah proses digitalisasi, kemudian tahap selanjutnya adalah metode desain partisipatif dengan calon pengguna, untuk menemukan desain final yang sesuai, berikut adalah hasil motif batik desain partisipatif : 


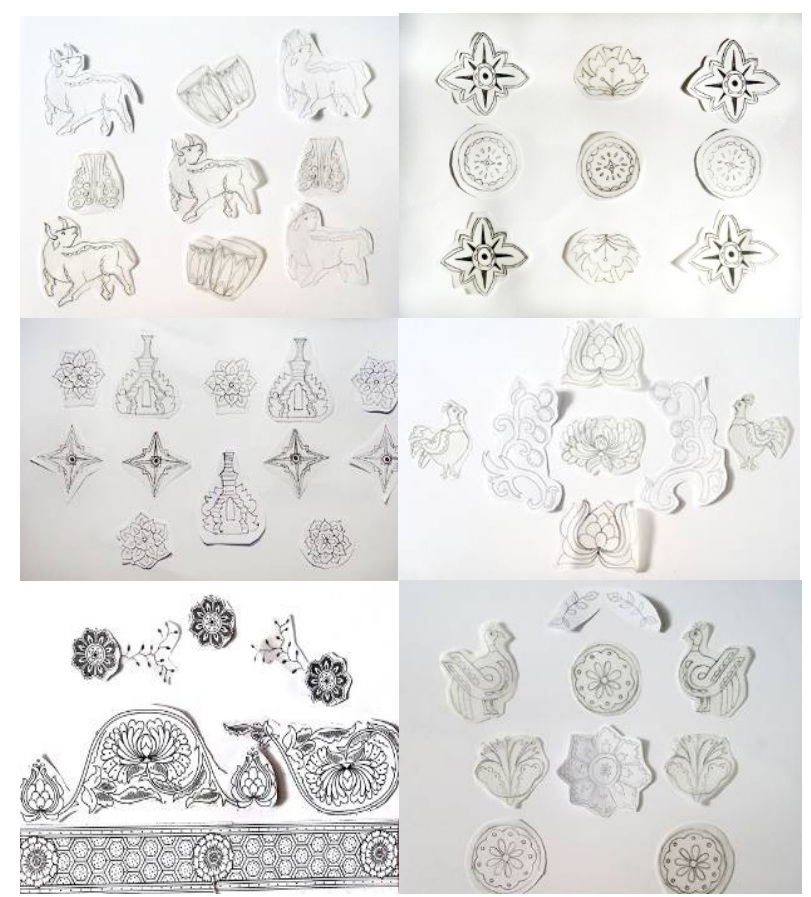

Gambar 8. Hasil desain partisipatif.

Sumber: Fajarwati, 2018

\section{Digitalisasi Motif}

Setelah proses desain partisipatif, kemudian tahap selanjutnya adalah mendigitalisasikan motif dari metode tersebut. Berikut adalah salah satu contoh motif yang sudah digitalisasi :

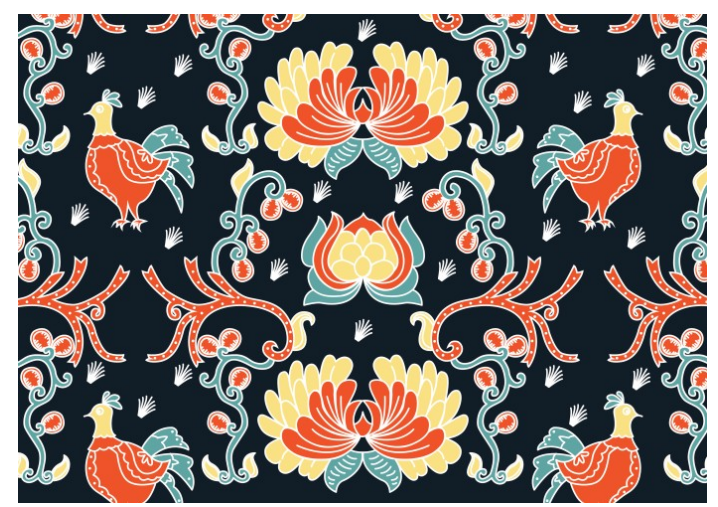

Gambar 9. Motif ayam sulur maja

Sumber: Fajarwati, 2018

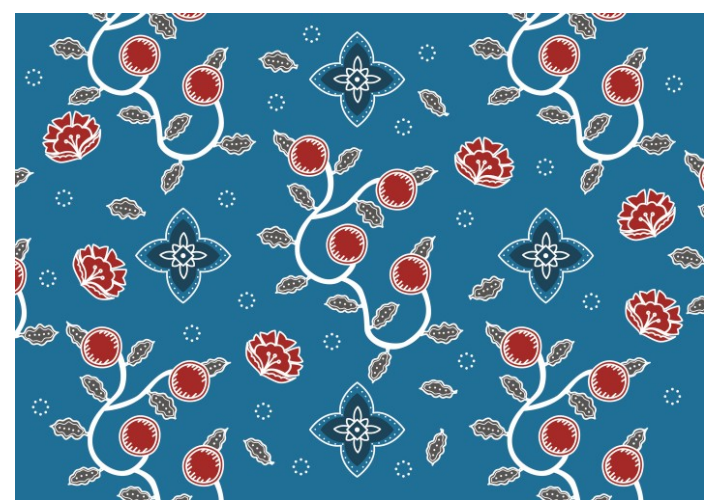

Gambar 10. Motif sulur surya maja.

Sumber: Fajarwati, 2018

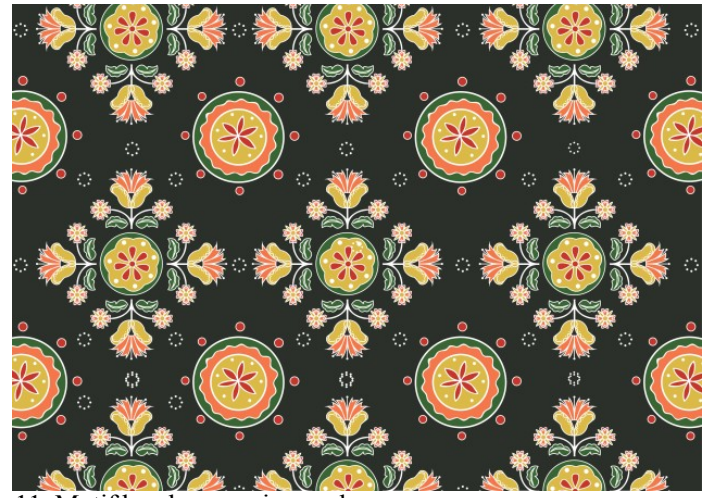

Gambar 11. Motif kembang mojo pecah.

Sumber: Fajarwati, 2018

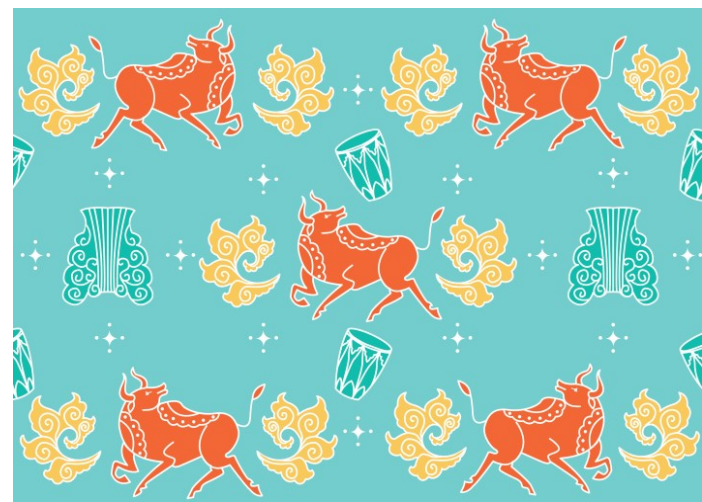

Gambar 12. Motif banteng canggu.

Sumber: Fajarwati, 2018

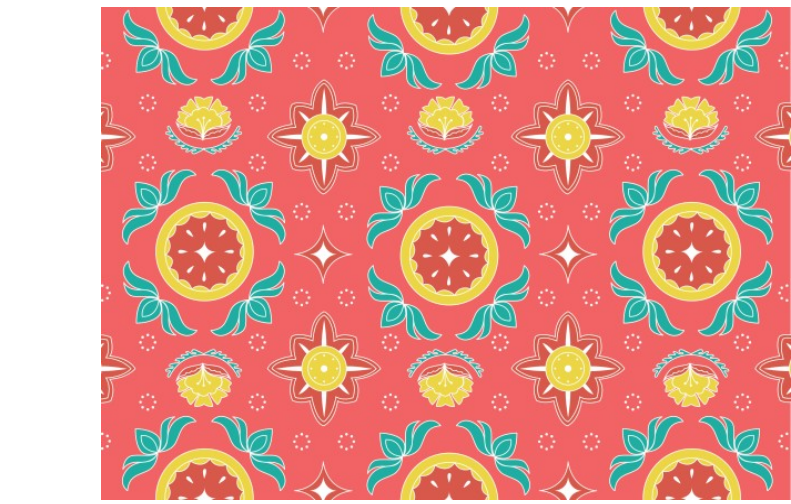

Gambar 13. Motif maja surya

Sumber: Fajarwati, 2018

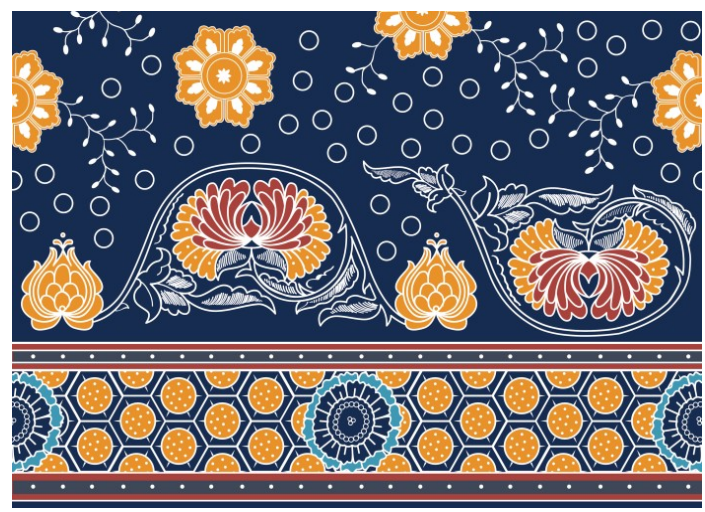

Gambar 14. Motif teratai kuncup mekar

Sumber: Fajarwati, 2018 


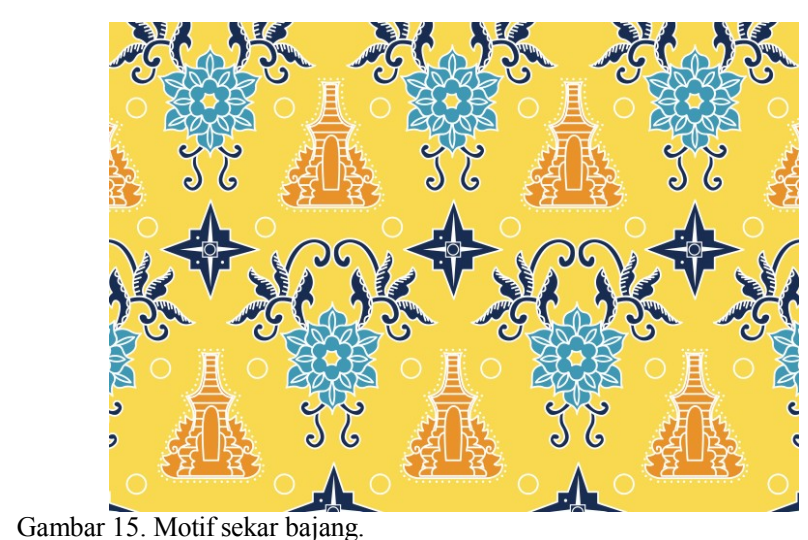

Sumber: Fajarwati, 2018

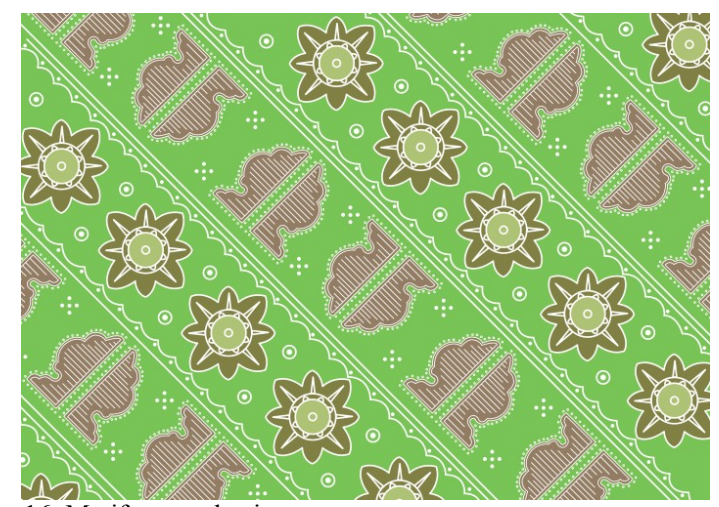

Gambar 16. Motif parang lawing.

Sumber: Fajarwati, 2018

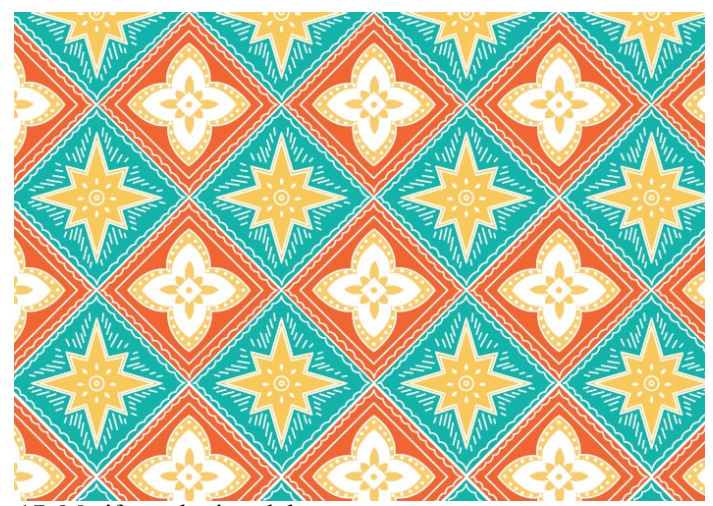

Gambar 17. Motif matahari ceplok.

Sumber: Fajarwati, 2018
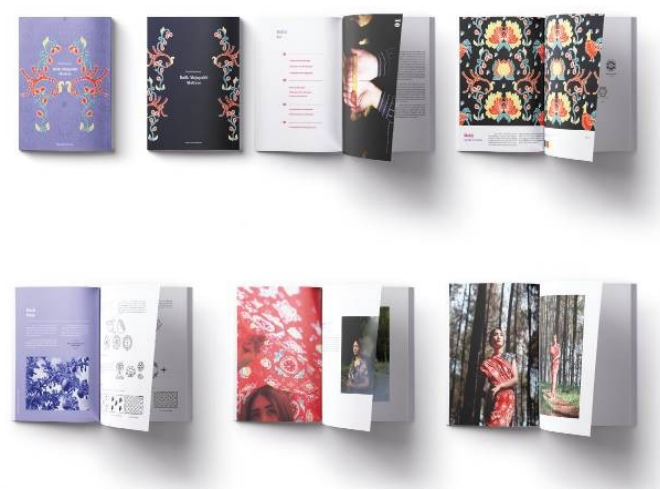

Gambar 18. Layout buku visual.

Sumber: Fajarwati, 2018

\section{KESIMPULAN}

1. Dengan adanya kolaborasi antara desainer dengan pengrajin batik, ditujukan untuk bertukar pikiran antara ide dan desain yang saling berhubungan satu sama lain.

2. Media yang dapat dijadikan penghubung antara desainer dan pengrajin adalah dengan media morphological matrix. Dengan material gambar ini metode desain partisipatif akan lebih mudah dilakukan dan dipahami oleh para pengrajin.

3. Perancangan eksplorasi desain motif batik Majapahit dengan metode desain partisipatif ini memiliki tingkat keberhasilan yang, karena beberapa desain akhir yang telah dilakukan pengrajin merasa sedikit terbantu dengan adanya beberapa motif baru yang dihasilkan dari potensi Mojokerto.

4. Pada uji coba yang dilakukan, target audiens dapat memahami informasi yang disampaikan karena menggunakan kalimat deskriptif. Walaupun sebagian target audiens belum memahami betul tentang metode desain partisipatif.

5. Pada bagian eksplorasi motif batik, target audiens menerima dan setuju dengan desain akhir yang dihasilkan yang lebih modern.

6. Pada bagian penamaan untuk setiap motif batik Majapahit yang baru, target audiens membutuhkan waktu yang relatif lama untuk mencerna namanya, namun ketika telah membaca deskripsinya audiens menjadi lebih tau dan antusias untuk menjelajahi motif batik selanjunya.

7. Eksplorasi batik khas Majapahit untuk target dewasa muda dibuat dengan menggunakan kaidah-kaidah batik tradisional namun tetap menggunakan ciri khas ikon modern yang mampu mempresentasikan Mojokerto dalam batik dengan sentuhan warna-warna khas batik Majapahit sebelumnya

\section{DAFTAR PUSTAKA}

[1] Amstrong, Hellen.2011. Participate Designing With User-Generated Content

[2] Anshori, Yusak \& Adi Kusrianto. 2011 ,Keeksotisan Batik Jawa Timur. Jakarta : PT. Elex Media Komputindo

[3] Hartono, Lili \& Mulyanto. 2018. Kesenian Reog Sebagai Sumber Ide Pengembangan Desain Motif Batik Ponorogo

[4] Kusrianto, Andi.2013.Batik Filosofi, Motif, dan Kegunaan.Yogyakarta:Penerbit Andi

[5] Kusumajaya, I Made. 2010. Mengenal Kepurbakalaan Majapahit Di Daerah Trowulan.

[6] Martin, Bella. 2012. Universal Methods of Design: 100 Wavs to Research Complex Problems, Develop Innovative Ideas, and Design Effective Solutions

[7] Musman, Asti \& Ambar B. Arini. 2011. Batik Warisan Adiluhung Nusantara. Yogyakarta: G-media

[8] Permanasari, Eka. 2018. Metode Desain Partisipatif Sebagai Model Pembangunan 6 RPTRA DKI Jakarta

[9] Rustan, Surianto. 2009, Layout Dasar \& Penerapannya. Penerbit PT Gramedia Pustaka Utama

[10] Sidiq, Mustar.2015. Batik Tulis A Technical Guide to Make Handwritten Batik.

[11] Wijaya, Niken 2012. Kajian Batik Majapahit Era Sekarang di Wilayah Mojokerto dengan Pendekatan Etnografi

[12] Yudhistira, Naufal Anggito. 2016. Dibalik Makna 99 Desain Batik. Penerbit: In Media 